Check for updates

Cite this: RSC Adv., 2018, 8, 13075

\title{
Nanoporous foam fabricated by dealloying AgAl thin film through supercritical fluid corrosion
}

\author{
Y. C. Liu, ${ }^{a}$ J. C. Huang, (D) ${ }^{\star a b}$ X. Wang, ${ }^{\text {ac }}$ M. T. Tsai ${ }^{a}$ and Z. K. Wang ${ }^{a}$
}

In this research, nanoporous silver foams are fabricated through dealloying $\mathrm{Ag}_{35} \mathrm{Al}_{65}$ (as atomic percentage, at\%) thin films in supercritical (SC) carbon dioxide. The supercritical $\mathrm{CO}_{2}$ is mixed with either $\mathrm{HCl}$, water or $\mathrm{H}_{2} \mathrm{C}_{2} \mathrm{O}_{4}$ aqueous solution as the solute in the reaction chamber. Due to the low tension of the supercritical fluid, under the best operating conditions, the surface area of the as-dealloyed $A_{9}{ }_{35} \mathrm{Al}_{65}$ can reach 4.6 $\mathrm{m}^{2} \mathrm{~g}^{-1}$, and the porosity volume fraction value can reach $74 \%$, with a smallest average pore size of around $75 \mathrm{~nm}$. In an optimum supercritical $\mathrm{CO}_{2}$ environment, a lower chemical concentration can be applied and it can take less time to form a uniform nanoporous structure.

Received 16th January 2018 Accepted 15th March 2018

DOI: $10.1039 / c 8 r a 00463 c$

rsc.li/rsc-advances materials, such as $\mathrm{Au}-\mathrm{Ag},{ }^{8} \mathrm{Ag}-\mathrm{Cu},{ }^{9} \mathrm{Ag}-\mathrm{Al},{ }^{2,10-13} \mathrm{Cu}-\mathrm{Zr},{ }^{14,15} \mathrm{Al}-\mathrm{Cu},{ }^{16}$ etc. Of all the alloy systems, the $\mathrm{Ag}-\mathrm{Al}$ alloy has received attention as the more efficient dealloying system for developing nanoporous Ag materials for various applications. ${ }^{17-19}$ Using the $\mathrm{Ag}-\mathrm{Al}$ system, chemical dealloying of Ag-Al alloys can be done in acidic or alkaline aqueous solution under free corrosion conditions. ${ }^{2,10-13}$ Using $5 \mathrm{wt} \% \mathrm{HCl}$ as the dealloying solution, a composition of from 15 to $40 \mathrm{at} \%$ of $\mathrm{Ag}$ in the precursor alloy can be dealloyed. ${ }^{2,11,12}$ If $5 \mathrm{wt} \% \mathrm{HCl}$ is replaced by $20 \mathrm{wt} \% \mathrm{NaOH}$, $\mathrm{Ag}_{2} \mathrm{Al}$ will still remain after dealloying. ${ }^{10}$ This result shows that using a $5 \mathrm{wt} \% \mathrm{HCl}$ dealloying solution has a better effect than using alkaline solution for selective corrosion with $\mathrm{Ag}$ and $\mathrm{Al}$. The typical chemical dealloying processes mentioned above usually require an elevated temperature $\left(60-120^{\circ} \mathrm{C}\right)$ and longer time $(60-$ $150 \mathrm{~min}$ ). For example, $\mathrm{Al}-\mathrm{Ag}$ ribbons can be dealloyed in $5 \mathrm{wt} \%$ $\mathrm{HCl}$ aqueous solution first at $60{ }^{\circ} \mathrm{C}$ for 30 minutes until no obvious bubbles emerge, and it then takes $120 \mathrm{~min}$ for the same solution at $90{ }^{\circ} \mathrm{C}$ to reach a dealloying state. ${ }^{11}$

Supercritical fluids (SCFs) offer the possibility to obtain new products using their unique characteristics, which are environmentally friendly and sustainable. ${ }^{20-22}$ SCFs are very dense gases with many properties superior to liquids or solvents. When a substance turns from a liquid or gas into a SCF, such a SCF would have a diffusion rate higher than that of the liquid and a viscosity ratio similar to that of the gas. For instance, the diffusion rate of liquid $\mathrm{H}_{2} \mathrm{O}$ is smaller than $10^{-5} \mathrm{~cm}^{2} \mathrm{~s}^{-1}$, with a viscosity ratio near $10^{-2} \mathrm{~g} \mathrm{~cm}^{-1} \mathrm{~s}^{-1}$, while supercritical water (SCW) has a diffusion rate of about $10^{-2}$ to $10^{-5} \mathrm{~cm}^{2} \mathrm{~s}^{-1}$ with a viscosity ratio of $10^{-3}$ to $10^{-6} \mathrm{~g} \mathrm{~cm}^{-1} \mathrm{~s}^{-1}$. ${ }^{23}$ The high diffusion rate provides a high diffusion flux in a SCF. Because almost all SCFs need to be formed at higher temperatures, the diffusion coefficient could increase a lot. Besides, a low viscosity ratio would let SCFs have strong and high penetration. With the above advantages, SCFs are recognized as an "ideal solution". ${ }^{21}$ Health and safely benefits are especially evident in the use of 
some of the most important SCFs, supercritical $\mathrm{CO}_{2}\left(\mathrm{SC} \mathrm{CO}_{2}\right.$ or SCC) and supercritical $\mathrm{H}_{2} \mathrm{O}$ (SCW). They are non-carcinogenic, nontoxic, non-mutagenic, non-flammable and thermodynamically stable. ${ }^{21}$ In this article, we will use $\mathrm{SC} \mathrm{CO}_{2}$ as the solution for chemical dealloying.

In 2012, Ruhl et al. ${ }^{24}$ demonstrated corrosion in supercritical $\mathrm{CO}_{2}$ via the diffusion of flue gas acids or water. Hydrochloric acid in $\mathrm{SC} \mathrm{CO}_{2}$ is very reactive and aggressive, including towards the austenitic autoclave material. Later in 2013, Morrish et al. ${ }^{25}$ used hexafluoroacetylacetone (hfacH) and $\mathrm{H}_{2} \mathrm{O}_{2}$ dissolved in supercritical $\mathrm{CO}_{2}$ to fabricate nanoporous copper. The good oxidation ability of $\mathrm{H}_{2} \mathrm{O}_{2}$ made $\mathrm{CuO}$ appear, and hfacH dissolved $\mathrm{CuO}$ in order to form a nanoporous structure. $\mathrm{Ag}-\mathrm{Cu}$ alloys exhibit eutectic phase behavior, allowing the composition of the two phases to be fixed while varying the average size of the phase domains from 250 to $1000 \mathrm{~nm}$, through increasing the annealing temperature. The selective removal of $\mathrm{Cu}$ from both phases was observed, and higher concentrations of the etching solution increased the etching rate between 45 and $75{ }^{\circ} \mathrm{C} .{ }^{25}$

Water has high solubility in $\mathrm{SC} \mathrm{CO}_{2},{ }^{26}$ and both water and $\mathrm{CO}_{2}$ are common materials we can obtain from nature. Normal reverse osmotic water has carbonate $\left(\mathrm{CO}_{3}{ }^{2-}\right)$ inside, because a small amount of $\mathrm{CO}_{2}$ gas in the atmosphere dissolves in water. The water has strong oxidative capacity in $\mathrm{SC}^{\mathrm{CO}_{2}}$, and could react with $\mathrm{Al}$. The alumina ion will hydrolyze because of carbonate, and form aluminum carbonate. Aluminum carbonate will form aluminum hydroxide after reacting with water. With $\mathrm{SC} \mathrm{CO}_{2}$ mixed with water, we could dealloy an $\mathrm{Ag}-\mathrm{Al}$ alloy.

From the research mentioned above, using $\mathrm{SC} \mathrm{CO}_{2}$ as the solvent to fabricate a nanoporous material can be regarded as an improvement over conventional chemical dealloying methods. It can not only use less acid to produce porous material, but can also accomplish the process in a shorter time. The high penetration and high solubility of supercritical fluids give the acid solute in $\mathrm{SC} \mathrm{CO}_{2}$ stronger oxidant ability, causing the chemical reaction rate to be much higher. Thus, this research examines the performance of dealloying in supercritical $\mathrm{CO}_{2}$ in comparison to conventional chemical dealloying.

\section{Experimental procedures}

In this study, AgAl thin films were prepared via sputtering deposition, using DC guns. As the two targets are both metals (silver and aluminum), it is more efficient to use DC sputtering. To ensure the quality of the thin films, the base pressure of the operating chamber was first set to $5 \times 10^{-7}$ torr. Then Ar was chosen to be the working gas. Both the $\mathrm{Ag}$ and $\mathrm{Al}$ guns had a pure elemental target with $99.99 \%$ purity. The $\mathrm{Al}$ and $\mathrm{Ag}$ guns were adjusted to $85 \mathrm{~W}$ and $15 \mathrm{~W}$, respectively. During deposition, the substrate was rotated with an average speed of $15 \mathrm{rpm}$ and the working distance was $120 \mathrm{~mm}$. All prepared thin films have a film thickness of 400-500 $\mathrm{nm}$. To protect the aluminum from severe oxidation $\left(\mathrm{Al}_{2} \mathrm{O}_{3}\right)$ after the sputtering process, we smeared a photoresist upon the thin film. The photoresist was composed of dimethyl sulfoxide (DMSO), so it could be easily dissolved using acetone. The resulting thin film composition is $\mathrm{Ag}_{35} \mathrm{Al}_{65}$ (at\%) within \pm 1 at\% accuracy.

Firstly, we used $\mathrm{Ag}_{35} \mathrm{Al}_{65}$ to observe the differences between dealloying with $\mathrm{HCl}$, water, and $\mathrm{H}_{2} \mathrm{C}_{2} \mathrm{O}_{4}$ in supercritical $\mathrm{CO}_{2}$. The supercritical $\mathrm{CO}_{2}$ pressure level was tried at 1200, 1600 and $2000 \mathrm{psi}$, and it is consistently found that the highest pressure of 2000 psi can result in a higher degree of dealloying. In parallel, the supercritical $\mathrm{CO}_{2}$ temperature was tried at 60, 90 and $120{ }^{\circ} \mathrm{C}$, and $120{ }^{\circ} \mathrm{C}$ consistently yields better efficiency. Thus, in this study, the SCF pressure and temperature are fixed at 2000 psi and $120{ }^{\circ} \mathrm{C}$.

Then, the $\mathrm{Ag}_{35} \mathrm{Al}_{65}$ thin films were dealloyed through supercritical fluid mixed with $0.05 \mathrm{ml}$ of $5 \mathrm{wt} \%$ or $1 \mathrm{M} \mathrm{HCl}, 5 \mathrm{ml}$ of water, or $0.25 \mathrm{ml}$ of $5 \mathrm{wt} \% \mathrm{H}_{2} \mathrm{C}_{2} \mathrm{O}_{4}$. The samples were characterized via different kinds of measurements. To compare the differences between dealloying in supercritical $\mathrm{CO}_{2}$ and conventional chemical dealloying, conventional chemical dealloying routines using $\mathrm{HCl}, \mathrm{H}_{2} \mathrm{C}_{2} \mathrm{O}_{4}$ and even water were also conducted in this study. Note that conventional chemical dealloying with water alone would not result in any corrosion.

The as-dealloyed $\mathrm{Ag}-\mathrm{Al}$ thin films were examined via X-ray diffraction (XRD), and the morphology and composition were identified using scanning electron microscopy (SEM) with energy dispersive X-ray spectrometry (EDS). The surface area and volume porosity of the as-dealloyed samples were evaluated via the Brunauer, Emmet and Teller (BET) test and ImageJ software. For the BET experiments, the first step of this process is to measure the weight of the sample and the weight of the sample with the glass tube. Then a process of degasification was carried out in order to get rid of the vapor existing inside the sample. The weights of the sample and glass tube were measured again in order to calculate the weight of the vapor. The weight of the sample minus the weight of the vapor equals the true weight of the sample. Then, the sample and the glass tube were put under an environment full of liquid nitrogen, and then the nitrogen gas filled the glass tube. The measurements of the ratio of surface area and the ratio of pore volume are carried out for $8 \mathrm{~h}$.

\section{Results and discussion}

\section{Thin film before dealloying}

Based on the $\mathrm{Al}-\mathrm{Ag}$ equilibrium phase diagram, ${ }^{27}$ there exists a $\beta-\mathrm{Ag}_{2} \mathrm{Al}$ phase (of hexagonal close packed HCP structure) for an $\mathrm{Al}$ content of around 25 to 40 at\%, and there is a eutectic point at around $\mathrm{Ag}_{34} \mathrm{Al}_{66}$ (at\%) for face-centered cubic (FCC) $\alpha$-Al and $\mathrm{HCP} \beta-\mathrm{Ag}_{2} \mathrm{Al}$. The composition of the present $\mathrm{Ag}_{35} \mathrm{Al}_{65}$ thin films would reside within the two-phase region, namely, FCC pure $\alpha-\mathrm{Al}+\mathrm{HCP} \beta-\mathrm{Ag}_{2} \mathrm{Al}$.

Fig. 1(a) presents a representative SEM secondary electron image (SEI) micrograph of the as-sputtered $\mathrm{Ag}_{35} \mathrm{Al}_{65}$ film before dealloying. The composition is confirmed to be $\mathrm{Ag}_{35} \mathrm{Al}_{65}$ (at\%) within \pm 1 at $\%$ accuracy. The XRD pattern of the as-deposited $\mathrm{Ag}_{35} \mathrm{Al}_{65}$ film before dealloying is shown in Fig. $1(\mathrm{~b})$. There is always pure $\mathrm{Al}$ (and/or some minor pure $\mathrm{Ag}$ ), resulting in the $\mathrm{Al}$ (111) peak and/or the $\mathrm{Ag}$ (111) peak at $38.8^{\circ}$ and $38.3^{\circ}$, respectively. These two peaks are very close to each other and difficult 

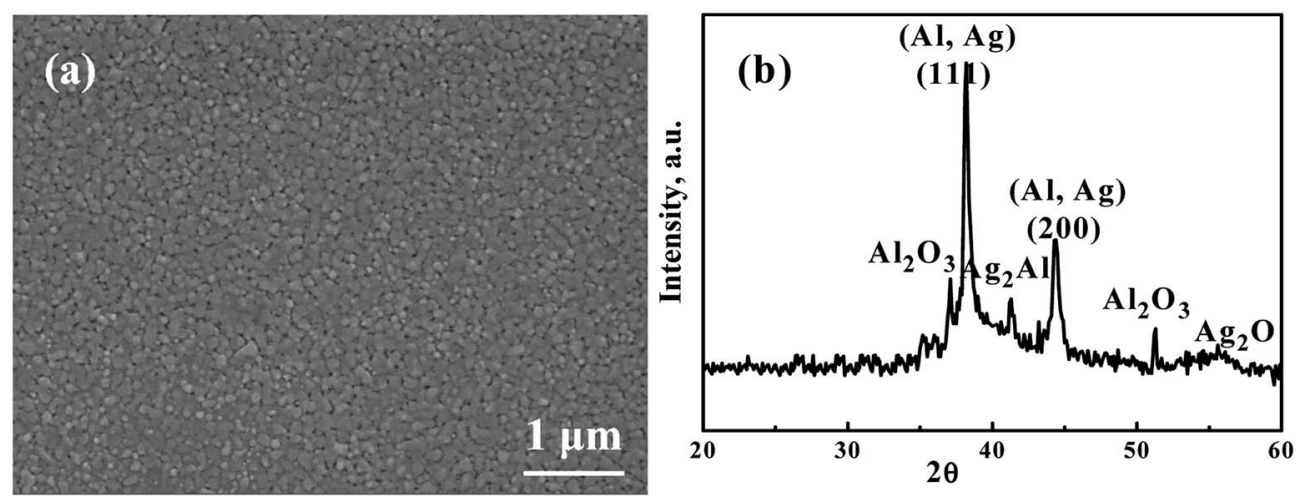

Fig. 1 A representative (a) SEM secondary electron image (SEI) micrograph and (b) XRD pattern of the as-sputtered $\mathrm{Ag}_{35} \mathrm{Al}_{65}$ films before dealloying.

to differentiate. When measured via SEM/EDS, the FCC phase is confirmed to be pure $\mathrm{Al}$. In addition, the $\mathrm{Ag}_{2} \mathrm{Al}$ phase can be indexed via the peak at $41.5^{\circ}$. The inevitable $\mathrm{Al}_{2} \mathrm{O}_{3}$ surface oxide is always seen for films with a high $\mathrm{Al}$ content, with peaks at $37.1^{\circ}$ and $52.2^{\circ}$. There seems to be a very minor $\mathrm{Ag}_{2} \mathrm{O}$ peak at about $55.5^{\circ}$.

\section{HCl in supercritical fluid}

From previous results, ${ }^{2,10-13}$ we know that $\mathrm{HCl}$ is an appropriate acid for selective etching in conventional chemical dealloying.
But using $\mathrm{HCl}$ under SCF, the problem is the surface tension, which causes devastation of the silver ligaments. In this study, we added a very small amount (only $0.05 \mathrm{ml}$ ) of $5 \mathrm{wt} \%$ or $1 \mathrm{M}$ $\mathrm{HCl}$ to the reaction chamber full of supercritical $\mathrm{CO}_{2}$, termed HC-SC. The results are quite similar, independent of $\mathrm{HCl}$ concentration. As shown in Fig. 2(a), a porous structure can be fabricated. But the pore size is about $2 \mu \mathrm{m}$ to $7 \mu \mathrm{m}$, with an average of about $4 \mu \mathrm{m}$ (Table 1 ), which is far larger than what we expected. The associated XRD pattern for the HC-SC dealloyed film in Fig. 2(b) indicates that the $\mathrm{Ag}_{2} \mathrm{Al}$ phase is still there: the dealloying is efficient.
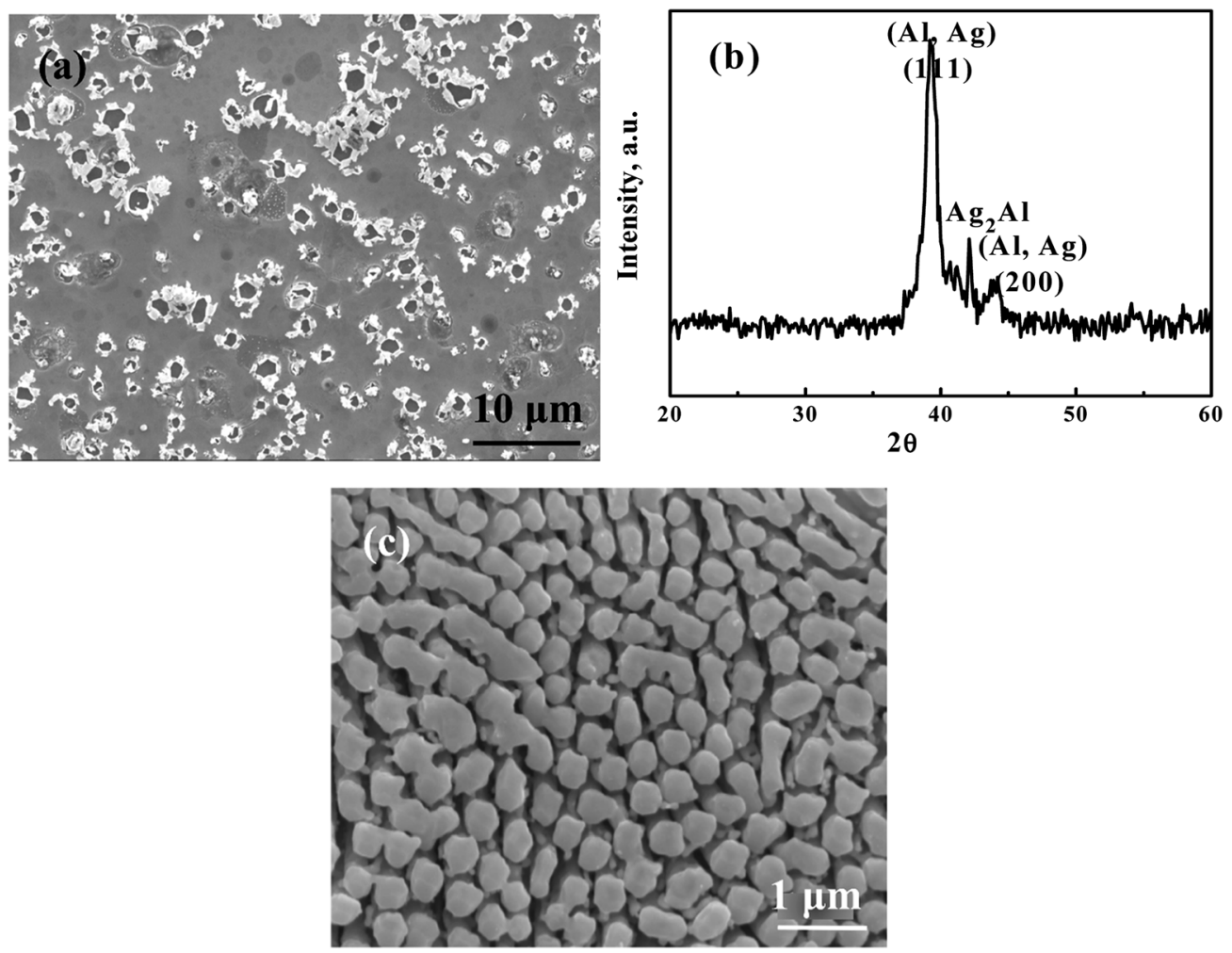

Fig. 2 (a) An SEM/SEl micrograph of AgAl thin film dealloyed using $0.05 \mathrm{ml}$ of $1 \mathrm{M} \mathrm{HCl}$ in supercritical $\mathrm{CO}_{2}$ for 3 min and (b) the associated XRD pattern, and (c) an SEM/SEI micrograph of film dealloyed via conventional chemical dealloying, using 5 wt $\% \mathrm{HCl}$ aqueous solution first at $60{ }^{\circ} \mathrm{C}$ for 30 min until no obvious bubbles emerged, followed by continuous dealloying in the same solution at $90^{\circ} \mathrm{C}$ for 120 min in order to further leach out residual $\mathrm{Al}$ in the samples. 
Table 1 Results from $\mathrm{Ag}_{35} \mathrm{Al}_{65}$ samples dealloyed with $0.05 \mathrm{ml}$ of $5 \mathrm{wt} \%$ or $1 \mathrm{M} \mathrm{HCl}$ in supercritical $\mathrm{CO}_{2}$ (termed $\mathrm{HC}-\mathrm{SC}$ ) at $120{ }^{\circ} \mathrm{C}$ and 2000 psi, for 3 and $5 \mathrm{~min}$

\begin{tabular}{llll}
\hline & Pre-dealloyed & $\begin{array}{l}\text { Dealloyed using HC-SC } \\
\text { at } 120{ }^{\circ} \mathrm{C} \text { and } 2000 \text { psi for } 3 \text { min }\end{array}$ & $\begin{array}{l}\text { Dealloyed using HC-SC } \\
\text { at } 120{ }^{\circ} \mathrm{C} \text { and } 2000 \text { psi for } 5 \text { min }\end{array}$ \\
\hline EDS results & $\mathrm{Ag}_{35} \mathrm{Al}_{65}$ & $\mathrm{Ag}_{35} \mathrm{Al}_{65}$ & $\mathrm{Ag}_{36} \mathrm{Al}_{64}$ \\
Surface area $\left(\mathrm{m}^{2} \mathrm{~g}^{-1}\right)$ & 0 & 0.5 & 1.3 \\
Porosity & $0 \%$ & $10 \%$ & $15 \%$ \\
Average pore size $(\mathrm{nm})$ & - & $\sim 4000$ & $\sim 4000$
\end{tabular}

Table 1 also lists the EDS results for the thin film dealloyed using $0.05 \mathrm{ml}$ of $5 \mathrm{wt} \%$ or $1 \mathrm{M} \mathrm{HCl}$ in supercritical $\mathrm{CO}_{2}$. The $\mathrm{Ag}$ and $\mathrm{Al}$ composition did not really change; the corrosion process is obviously not selective etching. The $\mathrm{HCl}$ in the SC reaction chamber is too aggressive and too corrosive; both $\mathrm{Ag}$ and $\mathrm{Al}$ are eaten. The surface area values for HC-SC dealloyed $\mathrm{Ag}_{35} \mathrm{Al}_{65}$ for 3 and $5 \mathrm{~min}$, determined using BET, are 0.5 and $1.3 \mathrm{~m}^{2} \mathrm{~g}^{-1}$, respectively, and the porosity volume fraction values are $10 \%$ and $15 \%$, respectively.

The reason for these circumstances is that $\mathrm{HCl}$ was not fully dissolved in the supercritical $\mathrm{CO}_{2}$. The supercritical fluid is known as a good solvent, and additive water or acid can act as a solute, forming a solution. The organic compound has low polarity, which makes it easier to dissolve in supercritical $\mathrm{CO}_{2}$. This is the reason why organic compounds like $\mathrm{H}_{2} \mathrm{C}_{2} \mathrm{O}_{4}$ can be fully dissolved in a supercritical fluid. On the contract, $\mathrm{HCl}$ has higher polarity. In the reaction chamber, it was not fully separated. Instead, the $\mathrm{HCl}$ liquid assembled and directly reacted with the thin film surfaces, including $\mathrm{Ag}$ and $\mathrm{Al}$. As a result, we can conclude that if we want to fabricate a homogeneous and non-devastated nanoporous structure using supercritical fluid, using an organic acid that can be fully dissolved in the supercritical fluid is a suitable choice.

\section{Comparison between conventional chemical and supercritical fluid dealloying with $\mathrm{HCl}$}

Previous researchers used different inorganic acid and organic acids to dealloy. In this research, we intend to compare the results while using $5 \mathrm{wt} \% \mathrm{HCl}$ typical chemical dealloying and $5 \mathrm{wt} \% \mathrm{HCl}$ in supercritical fluid. Using $\mathrm{HCl}$ is the most common way to fabricate nanoporous silver from AgAl thin film. The reaction of $\mathrm{Al}$ in $\mathrm{HCl}$ (and the water in dilute $\mathrm{HCl}$ solution) is described below: ${ }^{28}$

$$
\begin{gathered}
2 \mathrm{Al}+6 \mathrm{H}_{2} \mathrm{O} \rightarrow 2 \mathrm{Al}(\mathrm{OH})_{3}+3 \mathrm{H}_{2} \\
\mathrm{Al}(\mathrm{OH})_{3}+\mathrm{HCl} \rightarrow \mathrm{Al}(\mathrm{OH})_{2} \mathrm{Cl}+\mathrm{H}_{2} \mathrm{O}
\end{gathered}
$$

Herein the generation of $\mathrm{Al}(\mathrm{OH})_{2} \mathrm{Cl}$ is important; it makes the reaction able to proceed quickly. The aqueous solution of $5 \mathrm{wt} \% \mathrm{HCl}$ has higher surface tension than supercritical $\mathrm{CO}_{2}$. This would cause the solution to stay on the surface of the AgAl thin film for too long. $\mathrm{HCl}$ could not go through the tunnels between the ligaments. Instantly, it starts to etch $\mathrm{Ag}$ on the surface, as seen from Fig. 2(a). The reaction between $\mathrm{HCl}$ and $\mathrm{Ag}_{2} \mathrm{Al}$ is:

$$
\begin{gathered}
2 \mathrm{Ag}_{2} \mathrm{Al}+3 \mathrm{H}_{2} \mathrm{O} \rightarrow \mathrm{Al}_{2} \mathrm{O}_{3}+4 \mathrm{Ag}+3 \mathrm{H}_{2} \\
2 \mathrm{Ag}_{2} \mathrm{Al}+6 \mathrm{Cl}^{-}+3 \mathrm{H}_{2} \mathrm{O} \rightarrow \mathrm{Al}_{2} \mathrm{O}_{3}+4 \mathrm{Ag}+6 \mathrm{HCl} \\
2 \mathrm{Ag}+2 \mathrm{HCl} \rightarrow 2 \mathrm{AgCl}+\mathrm{H}_{2}
\end{gathered}
$$

In contrast, the microstructure of a sample dealloyed with $5 \mathrm{wt} \% \mathrm{HCl}$ using a typical chemical dealloy process is finer and more homogeneous, as shown in Fig. 2(c).

\section{Water in a supercritical fluid}

Since dealloying with $\mathrm{HCl}$ in SCF was too corrosive, water in SCF was tried. Fig. 3(a) shows an SEM secondary electron image (SEI) of an $\mathrm{Ag}_{35} \mathrm{Al}_{65}$ thin film dealloyed using water in
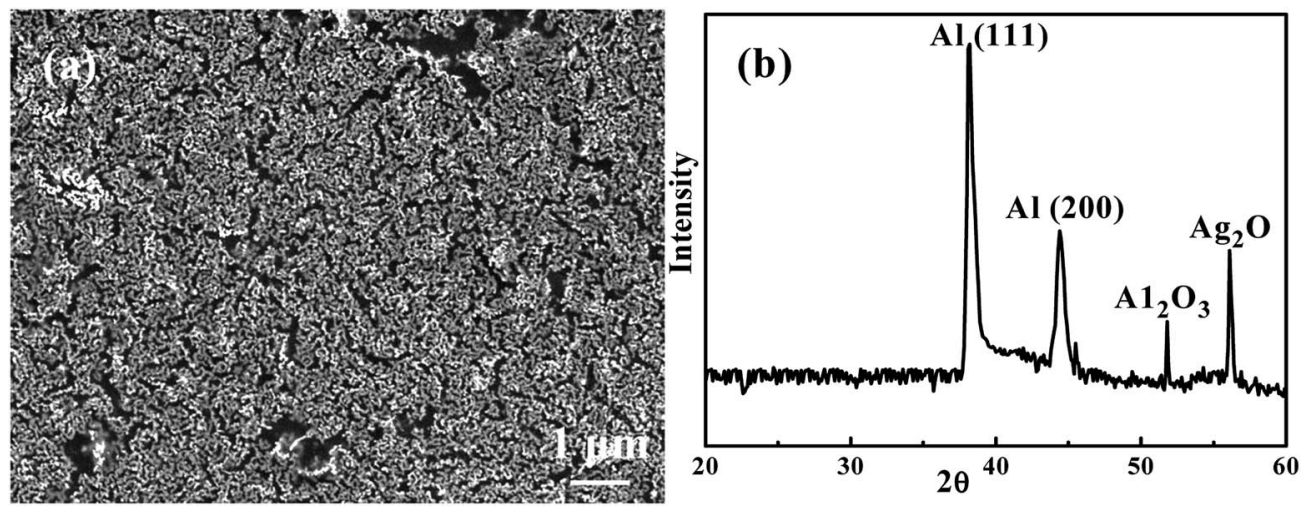

Fig. 3 (a) An SEM/SEI micrograph of $\mathrm{Ag}_{35} \mathrm{Al}_{65}$ thin film after being dealloyed using SC water for 60 min, and (b) the associated XRD pattern. 
Table 2 Results from $\mathrm{Ag}_{35} \mathrm{Al}_{65}$ samples dealloyed with water in supercritical $\mathrm{CO}_{2}$ (termed W-SC) at $120{ }^{\circ} \mathrm{C}$ and 2000 psi, for 30 and 60 min

\begin{tabular}{llll}
\hline & Pre-dealloyed & $\begin{array}{l}\text { Dealloyed using W-SC } \\
\text { at } 120{ }^{\circ} \mathrm{C} \text { and } 2000 \text { psi for } 30 \text { min }\end{array}$ & $\begin{array}{l}\text { Dealloyed using W-SC } \\
\text { at } 120{ }^{\circ} \mathrm{C} \text { and } 2000 \text { psi for } 60 \text { min }\end{array}$ \\
\hline EDS results & $\mathrm{Ag}_{35} \mathrm{Al}_{65}$ & $\mathrm{Ag}_{53} \mathrm{Al}_{47}$ & $\mathrm{Ag}_{59} \mathrm{Al}_{41}$ \\
Surface area $\left(\mathrm{m}^{2} \mathrm{~g}^{-1}\right)$ & 0 & 1.9 & 2.5 \\
Porosity & $0 \%$ & $25 \%$ & $32 \%$ \\
Average pore size $(\mathrm{nm})$ & - & $\sim 200$ & $\sim 200$
\end{tabular}

supercritical $\mathrm{CO}_{2}$ for $60 \mathrm{~min}$, termed as $\mathrm{W}$-SC. There are many ligaments on the surface. The distance between ligaments, equivalent to the pore size, is from 100 to $300 \mathrm{~nm}$, with an average value of $\sim 200 \mathrm{~nm}$. Fig. 3(b) is the associated XRD pattern of W-SC after $60 \mathrm{~min}$. The signal intensity of $\mathrm{Ag}_{2} \mathrm{Al}$ has decreased appreciably, while $\mathrm{Al}$ (111) and $\mathrm{Al}$ (200) signals are still strong. The corrosion started with the intermetallic compound $\mathrm{Ag}_{2} \mathrm{Al}$, because it has the higher potential energy. After corrosion, $\mathrm{Ag}_{2} \mathrm{O}$ would form, showing a peak at $56.5^{\circ}$.

Water has high solubility in supercritical $\mathrm{CO}_{2}$, and both water and $\mathrm{CO}_{2}$ are common materials we can obtain from nature. Normal reverse osmotic water has carbonate $\left(\mathrm{CO}_{3}{ }^{2-}\right)$ inside because a small amount of $\mathrm{CO}_{2}$ gas in the atmosphere dissolves in water. The water has strong oxidative capacity in supercritical $\mathrm{CO}_{2}$, which could react with alumina. The alumina ions will hydrolyze because of the presence of carbonate, and form aluminum carbonate. Aluminum carbonate will form aluminum hydroxide after reacting with water. Therefore, the reaction of $\mathrm{Ag}-\mathrm{Al}$ film in $\mathrm{SC}-\mathrm{W}$ is proposed below:

$$
\begin{gathered}
\mathrm{Al}+\mathrm{H}_{2} \mathrm{O} \rightarrow \mathrm{Al}_{2} \mathrm{O}_{3}+\mathrm{H}_{2} \\
2 \mathrm{Al}+6 \mathrm{H}_{2} \mathrm{O} \rightarrow 2 \mathrm{Al}(\mathrm{OH})_{3}+3 \mathrm{H}_{2} \\
\mathrm{Al}_{2} \mathrm{O}_{3}+\mathrm{CO}_{3}{ }^{2-} \rightarrow \mathrm{Al}_{2}\left(\mathrm{CO}_{3}\right)_{3} \\
\mathrm{Al}_{2}\left(\mathrm{CO}_{3}\right)_{3}+\mathrm{H}_{2} \mathrm{O} \rightarrow 2 \mathrm{Al}(\mathrm{OH})_{3}+3 \mathrm{CO}_{2} \\
\mathrm{Al}(\mathrm{OH})_{3}+3 \mathrm{H}^{+} \rightarrow \mathrm{Al}^{3+}+3 \mathrm{H}_{2} \mathrm{O}
\end{gathered}
$$

As for the $\mathrm{Ag}_{2} \mathrm{Al}$ part, it should proceed as follows:

$$
\begin{gathered}
2 \mathrm{Ag}_{2} \mathrm{Al}+3 \mathrm{H}_{2} \mathrm{O} \rightarrow \mathrm{Al}_{2} \mathrm{O}_{3}+4 \mathrm{Ag}+3 \mathrm{H}_{2} \\
2 \mathrm{Ag}_{2} \mathrm{Al}+\mathrm{H}_{2} \mathrm{CO}_{3}+3 \mathrm{H}_{2} \mathrm{O} \rightarrow \mathrm{Al}_{2}\left(\mathrm{CO}_{3}\right)_{3}+4 \mathrm{Ag}+3 \mathrm{H}_{2} \\
\mathrm{Ag}+\mathrm{H}_{2} \mathrm{O} \rightarrow \mathrm{Ag}_{2} \mathrm{O}+\mathrm{H}_{2}
\end{gathered}
$$

Table 2 summarizes the $\mathrm{W}$-SC results. With supercritical $\mathrm{CO}_{2}$ mixed with water, we could dealloy an $\mathrm{Ag}-\mathrm{Al}$ alloy, and fabricate nanoporous silver thin film. The surface area values for W-SC dealloyed $\mathrm{Ag}_{35} \mathrm{Al}_{65}$ for 30 and $60 \mathrm{~min}$, determined using BET, are 1.9 and $2.5 \mathrm{~m}^{2} \mathrm{~g}^{-1}$, respectively, and the porosity volume fraction values are $25 \%$ and $32 \%$, respectively. The reason for the lower porosity fraction might be due to the atomic percent of $\mathrm{Ag}$ in the $\mathrm{Ag}_{35} \mathrm{Al}_{65}$ thin film being only 35 at\%. If we increase the percentage of $\mathrm{Ag}$, it will fabricate a sponge structure with smaller pore sizes. Overall, W-SC dealloying appears to perform better than HC-SC, but the efficiency after 60 min is still below expectations. The third attempt was applying $\mathrm{H}_{2} \mathrm{C}_{2} \mathrm{O}_{4}$.

Note that water alone cannot dealloy AgAl using a conventional chemical dealloying method. Therefore, no comparison can be made regarding the dealloying differences between conventional chemical dealloying and supercritical fluid dealloying.

\section{$\mathrm{H}_{2} \mathrm{C}_{2} \mathrm{O}_{4}$ in supercritical fluid}

Fig. 4(a) is an SEI image showing the microstructure of $\mathrm{Ag}_{35} \mathrm{Al}_{65}$ thin film after it was dealloyed using $0.25 \mathrm{ml}$ of $5 \mathrm{wt} \% \mathrm{H}_{2} \mathrm{C}_{2} \mathrm{O}_{4}$ in supercritical fluid $\mathrm{CO}_{2}$, termed HCO-SC. Compared with the thin film dealloyed using water in supercritical fluid for $60 \mathrm{~min}$, the distance between ligaments, equivalent to the pore size, in the HCO-SC film is smaller $(\sim 100 \mathrm{~nm}$ versus $\sim 200 \mathrm{~nm})$. The
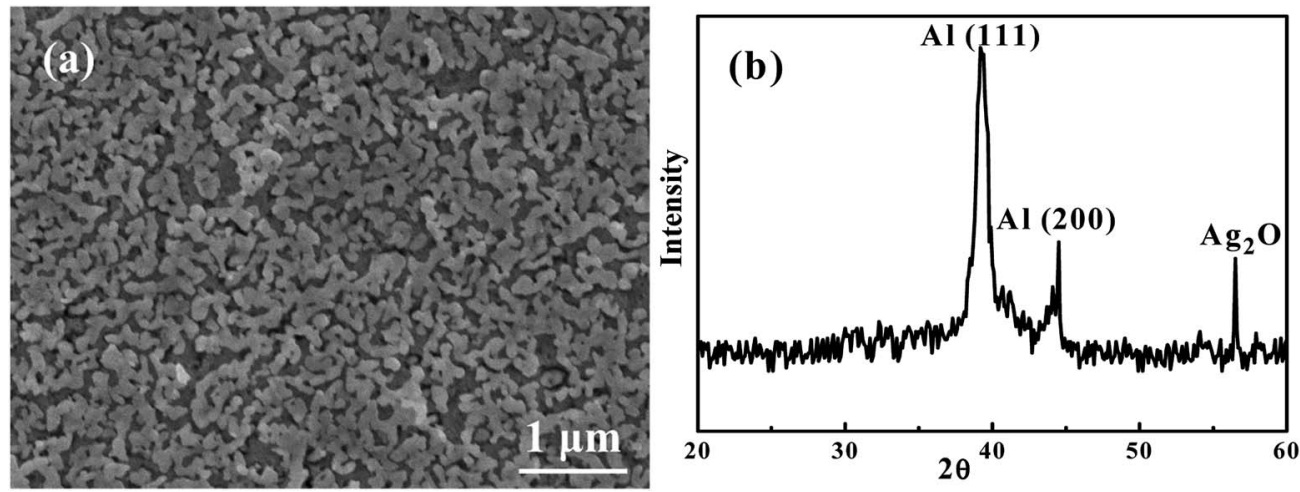

Fig. 4 (a) An SEM/SEI micrograph of $\mathrm{Ag}_{35} \mathrm{Al}_{65}$ thin film after being dealloyed using $\mathrm{SC}_{2} \mathrm{C}_{2} \mathrm{O}_{4}$ at 2000 psi for 20 min, and (b) the associated XRD pattern. 
Table 3 Results from $\mathrm{Ag}_{35} \mathrm{Al}_{65}$ samples dealloyed using $1 \mathrm{ml}$ of $\mathrm{H}_{2} \mathrm{C}_{2} \mathrm{O}_{4}$ in supercritical $\mathrm{CO}_{2}$ (termed $\mathrm{HCO}-\mathrm{SC}$ ) at $120^{\circ} \mathrm{C}$ and 2000 psi, for 10 and $20 \mathrm{~min}$

\begin{tabular}{llll}
\hline & Pre-dealloyed & $\begin{array}{l}\text { Dealloyed using HCO-SC } \\
\text { at } 120{ }^{\circ} \mathrm{C} \text { and } 2000 \text { psi for } 10 \text { min }\end{array}$ & $\begin{array}{l}\text { Dealloyed using HCO-SC } \\
\text { at } 120{ }^{\circ} \mathrm{C} \text { and } 2000 \text { psi for } 20 \text { min }\end{array}$ \\
\hline EDS results & $\mathrm{Ag}_{35} \mathrm{Al}_{65}$ & $\mathrm{Ag}_{75} \mathrm{Al}_{25}$ & $\mathrm{Ag}_{88} \mathrm{Al}_{12}$ \\
Surface area $\left(\mathrm{m}^{2} \mathrm{~g}^{-1}\right)$ & 0 & 2.9 & 4.5 \\
Porosity & $0 \%$ & $37 \%$ & $72 \%$ \\
Average pore size $(\mathrm{nm})$ & - & $\sim 100$ & $\sim 100$
\end{tabular}
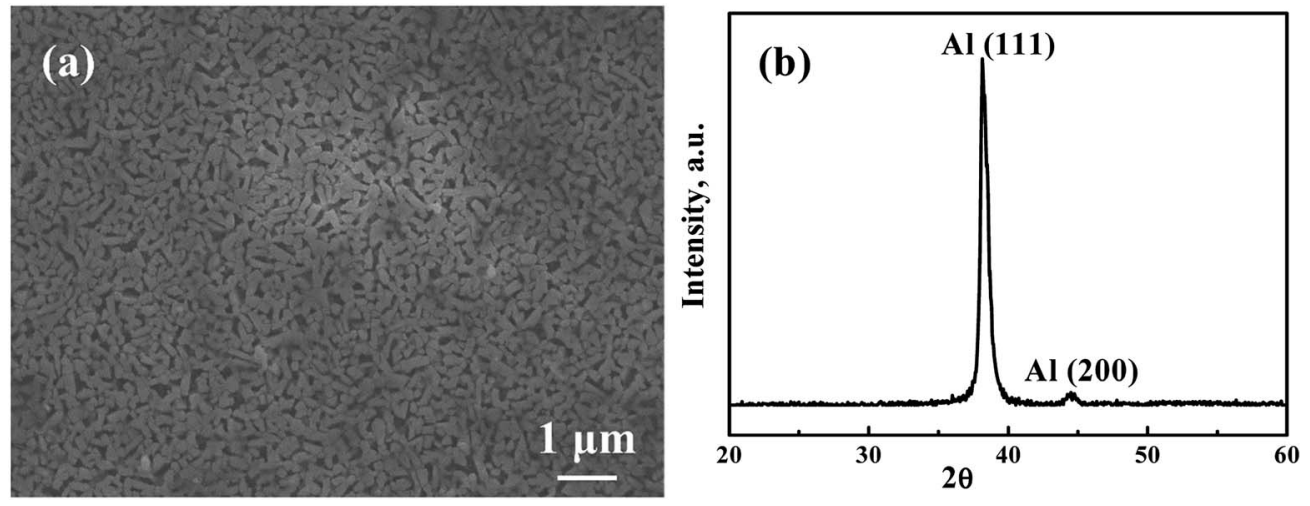

Fig. 5 (a) An SEM/SEI micrograph of annealed $\mathrm{Ag}_{35} \mathrm{Al}_{65}$ thin film dealloyed using SCF with $1 \mathrm{ml}$ of 5 wt $\% \mathrm{H}_{2} \mathrm{C}_{2} \mathrm{O}_{4}$ under conditions of $120{ }^{\circ} \mathrm{C}$ and 2000 psi for 20 min, and (b) the associated XRD pattern.

associated XRD pattern of the $\mathrm{Ag}_{35} \mathrm{Al}_{65}$ thin film after it was dealloyed by HCO-SC is presented in Fig. 4(b). The $\mathrm{Ag}_{2} \mathrm{Al}$ signal is completely gone, and the signals of $\mathrm{Al}$ (111) and $\mathrm{Al}$ (200) have decreased a lot compared with those of the as-sputtered thin film in Fig. 1(b).

The water in the $\mathrm{H}_{2} \mathrm{C}_{2} \mathrm{O}_{4}$ dilute solution mixed with supercritical $\mathrm{CO}_{2}$ has strong oxidizing abilities. The strong oxidizing abilities oxidize aluminum to $\mathrm{Al}(\mathrm{OH})_{3}$, which reacted with $\mathrm{H}_{2} \mathrm{C}_{2} \mathrm{O}_{4}$ and formed $\mathrm{Al}_{2}\left(\mathrm{C}_{2} \mathrm{O}_{4}\right)_{3}$. $\mathrm{Al}_{2}\left(\mathrm{C}_{2} \mathrm{O}_{4}\right)_{3}$ can be dissolved and taken away with the supercritical fluid when the experiment is over. According to Kotz et al. ${ }^{28}$ the reaction between $\mathrm{Al}, \mathrm{H}_{2} \mathrm{C}_{2} \mathrm{O}_{4}$ and water (within the $\mathrm{H}_{2} \mathrm{C}_{2} \mathrm{O}_{4}$ dilute solution) proceeds as presented below:

$$
\begin{aligned}
2 \mathrm{Al}+6 \mathrm{H}_{2} \mathrm{O} & \rightarrow 2 \mathrm{Al}(\mathrm{OH})_{3}+3 \mathrm{H}_{2} \\
2 \mathrm{Al}(\mathrm{OH})_{3}+3 \mathrm{H}_{2} \mathrm{C}_{2} \mathrm{O}_{4} & \rightarrow \mathrm{Al}^{3+}+\mathrm{C}_{2} \mathrm{O}_{4}{ }^{2-}+6 \mathrm{H}_{2} \mathrm{O}
\end{aligned}
$$

As for the $\mathrm{Ag}_{2} \mathrm{Al}$ part, this should proceed as follows:

$$
\begin{gathered}
2 \mathrm{Ag}_{2} \mathrm{Al}+3 \mathrm{H}_{2} \mathrm{O} \rightarrow \mathrm{Al}_{2} \mathrm{O}_{3}+4 \mathrm{Ag}+3 \mathrm{H}_{2} \\
2 \mathrm{Ag}_{2} \mathrm{Al}+\mathrm{C}_{2} \mathrm{O}_{4}{ }^{2-}+\mathrm{H}_{2} \mathrm{O} \rightarrow \mathrm{Al}_{2} \mathrm{O}_{3}+4 \mathrm{Ag}+\mathrm{H}_{2} \mathrm{C}_{2} \mathrm{O}_{4} \\
\mathrm{Ag}+\mathrm{H}_{2} \mathrm{O} \rightarrow \mathrm{Ag}_{2} \mathrm{O}+\mathrm{H}_{2}
\end{gathered}
$$

Table 3 lists the EDS results for the dealloyed thin films. The thin film, after being dealloyed under conditions of $120^{\circ} \mathrm{C}$ and $2000 \mathrm{psi}$, shows an obvious drop in $\mathrm{Al}$ content from $65 \%$ down to $25 \%$ in $10 \mathrm{~min}$, and then to $12 \%$ in $20 \mathrm{~min}$. This proves that using supercritical $\mathrm{CO}_{2}$ as the solvent really increases the selective etching of an AgAl alloy. The surface area values for HCO-SC dealloyed $\mathrm{Ag}_{35} \mathrm{Al}_{65}$ for 10 and $20 \mathrm{~min}$, determined using BET, are 2.9 and $4.5 \mathrm{~m}^{2} \mathrm{~g}^{-1}$, respectively, and the porosity volume fraction values are $37 \%$ and $72 \%$, respectively.

\section{$\mathrm{H}_{2} \mathrm{C}_{2} \mathrm{O}_{4}$ in supercritical fluid for annealed samples}

After physical vapor deposition, an AgAl alloy sputtered thin film on a silicon substrate can be loose in some locations, and

Table 4 Results from samples annealed for 20 min dealloyed using $1 \mathrm{ml}$ of $5 \mathrm{wt} \% \mathrm{H}_{2} \mathrm{C}_{2} \mathrm{O}_{4}$ in supercritical fluid $\mathrm{CO}_{2}$ (termed $\mathrm{HCO}-\mathrm{SC}$ ) at $120{ }^{\circ} \mathrm{C}$ and 2000 psi, for 10 and 20 min

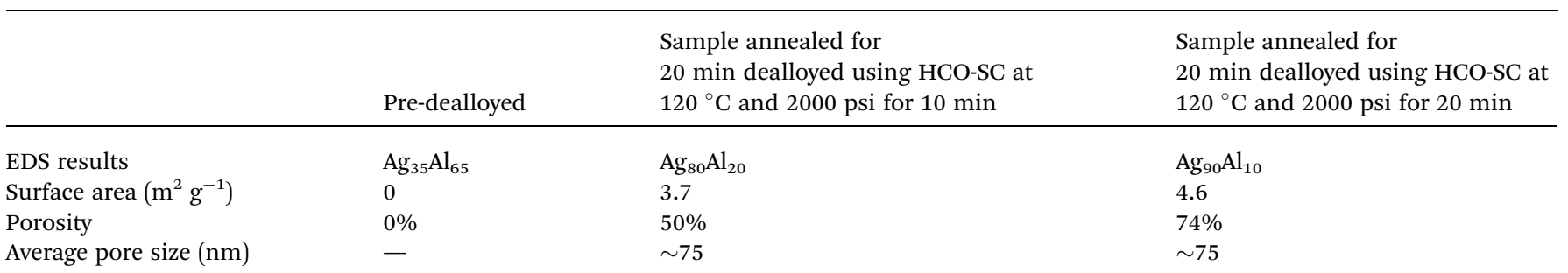




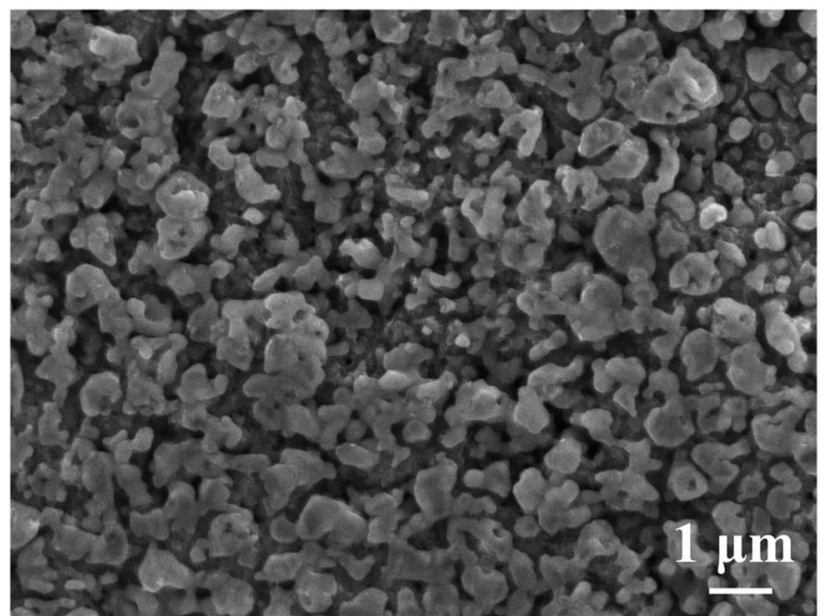

Fig. 6 An SEM/SEI micrograph showing the conventional chemical dealloying microstructure of $\mathrm{Ag}_{35} \mathrm{Al}_{65}$ dealloyed with 10 wt\% $\mathrm{H}_{2} \mathrm{C}_{2} \mathrm{O}_{4}$ for $60 \mathrm{~min}$ to form the nanoporous structure.

$\mathrm{Ag}$ and $\mathrm{Al}$ might not be co-sputtered completely uniformly. A post-sputtering annealing process might be a method to improve this problem. We thus place the $\mathrm{Ag}_{35} \mathrm{Al}_{65}$ films in an annealing chamber and conduct annealing at $400{ }^{\circ} \mathrm{C}$ for $20 \mathrm{~min}$ under an $\mathrm{Ar}$ atmosphere.

Fig. 5(a) is the annealed $\mathrm{Ag}_{35} \mathrm{Al}_{65}$ thin film dealloyed using $0.25 \mathrm{ml}$ of $5 \mathrm{wt} \% \mathrm{H}_{2} \mathrm{C}_{2} \mathrm{O}_{4}$ in supercritical fluid $\mathrm{CO}_{2}$ under the conditions of $120{ }^{\circ} \mathrm{C}$ and $2000 \mathrm{psi}$. The ligament size is about $150 \mathrm{~nm}$, and the pore size is $50 \mathrm{~nm}$ to $100 \mathrm{~nm}$, with an average size of $\sim 75 \mathrm{~nm}$. The XRD scan of the annealed and dealloyed samples is basically the same as that in Fig. 5(b). Note that there are no peaks relating to $\mathrm{Al}_{2} \mathrm{O}_{3}$ or $\mathrm{Ag}_{2} \mathrm{O}$. The pore size is smaller than any other research reported. Table 4 shows the EDS results for the annealed thin film. From the atomic percentages, it is obvious that $\mathrm{Al}$ has been selectively etched. Most importantly, there is no signal from oxygen. It seems that the oxygen trapped in the sputtered films might have been released from the films into the Ar atmosphere during annealing. Normally, the dealloying process in supercritical fluid will lead to the formation of some metallic oxides. But the oxides become minimal in the annealed and then dealloyed films, consistent with the findings from XRD, as shown in
Fig. 5(b). The surface area values for HCO-SC annealed and then dealloyed $\mathrm{Ag}_{35} \mathrm{Al}_{65}$ for 10 and $20 \mathrm{~min}$, determined using BET, are 3.7 and $4.6 \mathrm{~m}^{2} \mathrm{~g}^{-1}$, respectively, and the porosity volume fraction values are $50 \%$ and $74 \%$, respectively.

\section{Comparison between conventional chemical and supercritical fluid dealloying using $\mathrm{H}_{2} \mathrm{C}_{2} \mathrm{O}_{4}$}

From the SEM image in Fig. 6, typical chemical dealloying using 10 wt $\% \mathrm{H}_{2} \mathrm{C}_{2} \mathrm{O}_{4}$ could form a nanoporous structure within 60-600 min. And from higher magnifications, we can discover that the pore size varies from $100 \mathrm{~nm}$ to $1000 \mathrm{~nm}$, which is non-uniform.

On the other hand, the alloy dealloyed using supercritical fluid only needs to use a very small amount of chemical, $0.25 \mathrm{ml}$, in SCF for only 20 min to achieve a fully etched pore structure, as shown in Fig. 4(a) and 5(a). From the SEM image, we found that the pore size is uniform and much smaller than the one obtained upon typical chemical dealloying with $\mathrm{H}_{2} \mathrm{C}_{2} \mathrm{O}_{4}$. The promising nanoporous structures are well demonstrated.

\section{Closing remarks}

For an overall comparison of conventional and supercritical dealloying, the benefits of applying the latter can be demonstrated by the data listed in Table 5 . Conventional chemical dealloying can be done using $\mathrm{HCl}, \mathrm{NaOH}, \mathrm{H}_{2} \mathrm{C}_{2} \mathrm{O}_{4}, \mathrm{HSO}_{4}$, etc. The chemical usually needs to be present in the amount of a few liters, with a chemical concentration in the level of 5-10 wt\%. The time required to complete dealloying would range from 30 to $600 \mathrm{~min}$.

On the other hand, supercritical fluid dealloying requires the chemical in a much smaller amount, from 0.05 to $0.25 \mathrm{ml}$, with the chemical concentration comparable or lower, and the dealloying time period appreciably shortened down to about 20 min. Even plain water in SCF exposes selective dealloying capabilities. Furthermore, the resulting open-cell pores can be highly uniform and the pore size can be apparently smaller, down to $\sim 75 \mathrm{~nm}$

Table 5 Comparison between conventional chemical and supercritical dealloying of an Ag-Al system

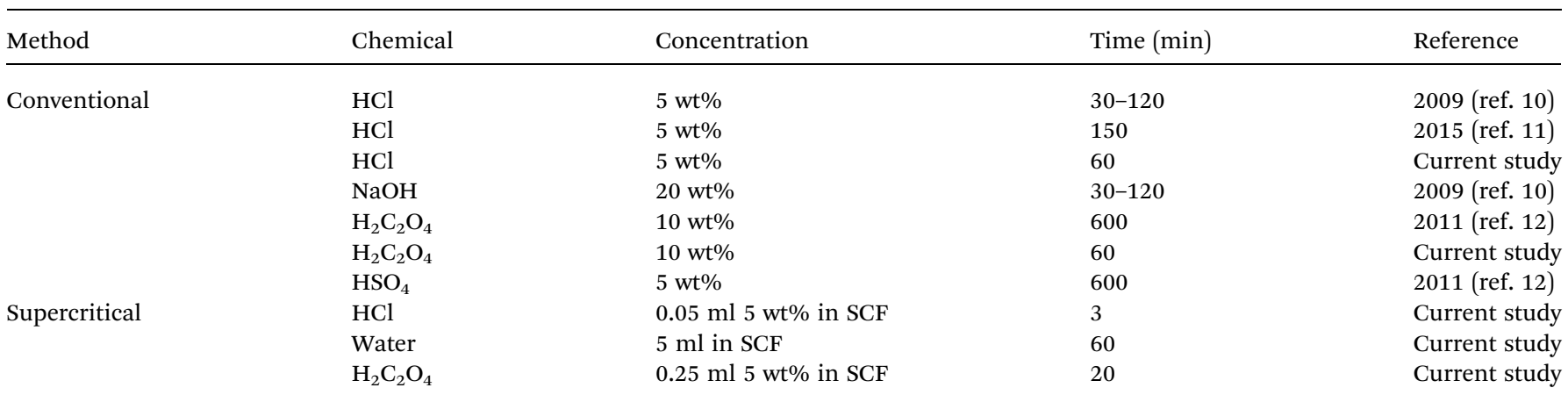




\section{Conclusions}

Based on the current study, the following conclusions can be drawn: (1) when using a supercritical fluid as the solvent in the dealloying corrosion process, it takes much less time and a lower chemical concentration than traditional selective etching and electrochemistry. The SCF performs much better in an environmentally friendly matter in fabricating nanoporous structures for catalysts, optics, sensors, filters, etc.; (2) it is found that a higher temperature and pressure would accelerate SCF dealloying. In this study, it is found that $120{ }^{\circ} \mathrm{C}$ and 2000 psi would be a suitable combination; (3) under normal temperatures and pressures, water does not have the ability to dealloy into a nanoporous structure. But in supercritical $\mathrm{CO}_{2}$, with higher temperature and higher pressure, water has the high oxidizing ability to do so; (4) according to previous research, $\mathrm{H}_{2} \mathrm{C}_{2} \mathrm{O}_{4}$ is a suitable acid to form nanoporous silver, but it would need 60-600 min to result in successful dealloying, and the concentration needs to be as high as $10 \mathrm{wt} \%$. Now, using supercritical $\mathrm{CO}_{2}$ as a solvent, we only need $0.25 \mathrm{ml}$ of $5 \mathrm{wt} \% \mathrm{H}_{2} \mathrm{C}_{2} \mathrm{O}_{4}$ and $20 \mathrm{~min}$ to form a nanoporous structure. The average pore size can be as low as $75 \mathrm{~nm}$, which is much smaller and more uniform than in structures prepared using conventional chemical dealloying. The benefits of applying SCF are apparent and well demonstrated.

\section{Conflicts of interest}

There are no conflicts to declare.

\section{Acknowledgements}

The authors gratefully acknowledge support from the Ministry of Science and Technology of Taiwan, ROC, under the grant no. MOST-105-2221-E-110-019-MY31, and from the City University of Hong Kong, under the grant no. 9380088.

\section{References}

1 S. Polarz and B. J. Smarsly, J. Nanosci. Nanotechnol., 2002, 6, 581-612.

2 C. X. Xu, J. X. Su, X. H. Xu, P. P. Liu, H. J. Zhao, F. Tian and Y. Ding, J. Am. Chem. Soc., 2007, 129, 42-43.

3 Y. Yin, J. Zhao, L. Qin, Y. Yang and L. He, RSC Adv., 2016, 6, 63358-63364.

4 L. F. Liu, E. Pippel, R. Scholz and U. Gösele, Nano Lett., 2009, 9, 4352-4358.

5 M. C. Tai, A. Gentle, M. D. Arnold and M. B. Cortie, $R S C$ Adv., 2016, 6, 85773-85778.
6 L. H. Qian, W. Shen, B. Das, B. Shen and G. W. Qin, Chem. Phys. Lett., 2009, 479, 259-263.

7 A. K. M. Kafi, A. Ahmadalinezhad, J. P. Wang, D. F. Thomas and A. Chen, Biosens. Bioelectron., 2010, 25, 2458-2463.

8 J. Erlebacher, A. Karma, N. Dimitrov and K. Sieradzki, Nature, 2001, 410, 450-453.

9 G. Li, Z. Sun, S. Yang, B. Ding, S. Yang, Z. Yang and F. Wang, Solid State Sci., 2011, 13, 1379-1384.

10 X. Wang, C. Zhao, W. Wang and Z. Zhang, J. Phys. Chem. C, 2009, 113, 13139-13150.

11 T. Y. Wu, X. Wang, J. C. Huang, W. Y. Tsai, Y. Y. Chu, S. Y. Chen and X. H. Du, Metall. Mater. Trans. B, 2015, 46, 2296-2304.

12 T. Song, Y. Gao, Z. Zhang and Q. Zhai, CrystEngComm, 2011, 13, 7058-7067.

13 X. Zhang, G. Li, X. Song, S. Yang and Z. Sun, RSC Adv., 2017, 7, 32442-32451.

14 N. Wang, Y. Pan, S. Wu, E. Zhang and W. Dai, RSC Adv., 2017, 7, 43255-43265.

15 H. B. Lu and F. H. Wang, J. Alloys Compd., 2008, 465, 139144.

16 Y. Zhao, X. Wang, J. C. Huang, X. Chen, L. Gao and M. Wu, Mater. Lett., 2016, 183, 165-169.

17 H. Qiu, Z. Zhang, X. Huang and Y. Qu, ChemPhysChem, 2011, 12, 2118-2123.

18 T. Song, Y. Gao, Z. Zhang and Q. Zhai, CrystEngComm, 2011, 13, 7058-7067.

19 M. S. Kim and H. Nishikawa, J. Mater. Sci., 2013, 48, 56455652.

20 H. B. Lu and F. H. Wang, J. Alloys Compd., 2008, 465, 139144.

21 P. Munshi and S. Bhaduri, Curr. Sci., 2009, 97, 63-72.

22 Z. Knez, E. Markocic, M. Leitgeb, M. Primozic, M. K. Hrncic and M. Skerget, Energy, 2014, 77, 235-243.

23 E. Szekely, B. Simándi, E. Fogassy, S. Kemény and I. Kmecz, Chirality, 2007, 15, 783-786.

24 A. S. Ruhl and A. Kranzmann, J. Supercrit. Fluids, 2012, 68, 81-86.

25 R. Morrish and A. J. Muscat, J. Phys. Chem. C, 2013, 117, 12071-12077.

26 A. N. Sabirzyanov, A. P. Il'in, A. R. Akhunov and F. M. Gumerov, High Temp., 2002, 40, 203-206.

27 Nuclear Thermodynamic Database, ed. B. Cheynet, Saint Martin D' Heres, France, 1996.

28 J. C. Kotz, P. M. Treichel and J. Townsend, Chemistry \& Chemical Reactivity, Cengage Learning, USA, 1987. 